\title{
New Era Posyandu
}

\section{Nama : Rizki Akbar}

Email: s130118061@student.ubaya.ac.id

Begitu pentingnya layanan kesehatan bagi masyarakat terutama untuk orang yang sudah berumur atau sudah lanjut usia. Identik dengan lansia pasti tidak jauh-jauh dari kata posyandu, posyandu sendiri ialah puskesmas berbasis masyarakat yang umumnya terletak di desa-desa dan posyandu ternyata dapat dibagi menjadi dua, yaitu Posyandu untuk Balita dan Posyandu untuk Lansia. Dalam wilayah Surabaya dan Malang ingin menerapkan beberapa prinsip untuk dilaksanan di titik-titik posyandu yang telah ditentukan. 1). Membuat LTC untuk komunitas lokal agar dapat membangun layanan kesehatan untuk lansia yang lebih baik. 2). Meningkatkan aksesbilitas dengan adanya dukungan dari pihak internal seperti keluarga agar dapat membantu lansia mendapatkan layanan kesehatan tanpa mengkhawatirkan pihak keluarga sendiri. 3). Perlu juga meningkatkan akseptabilitas LTC itu sendiri dengan adanya dukungan dari budaya dan agama setempat terutama dalam hal bahasa. 4). Yang terakhir perlunya mengukur kualitas LTC dari masing-masing posyandu apakah sudah tepat dan sesuai prosedur, hal ini dilakukan secara objektif serta subjektif. Jika penerapan layanan kesehatan untuk lansia di Indonesia salah satunya seperti yang telah dijelaskan, maka berbeda dengan negara lain. Ambil contoh negara Jepang, negara ini menerapkan kebijakan implikasi reformasi guna untuk perawatan lansia dan Jepang juga menerapkan skema asuransi baru dimana berbasis Asuransi Skema Jangka Panjang demi mencegah isolasi sosial dan menanggapi situasi darurat ( Kawakami, 2014 ).

Setelah melakukan wawancara dan pengamatan, saya ambil contoh disini, yaitu kakek saya. Beliau bernama Mugeni yang sudah berusia 78 tahun dan mempunyai istri yang bernama Murti yang berusia 73 tahun. Beliau ini telah dikaruniai 5 orang anak, 1 anak lakilaki dan 4 anak perempuan. Beliau sendiri menempuh pendidikan terakhir di tamatan Sekolah Dasar ( SD ) dan tinggal dengan anak perempuannya yang ke-4. Pak Mugeni ini memiliki beberapa penyakit, salah satunya gula darah. Untuk menangani penyakitnya tersebut, anakanaknya selalu berusaha untuk menjaga pola makannya agar terhindar dari makanan yang mengandung gula dan santan terutama. Dan setiap minggu selalu dibawa ke layanan kesehatan untuk mengecek gula darahnya apakah ada perkembangan atau tidak agar dapat selalu terkontrol dan syukurnya pelayanan yang diberikan cukup baik untuk melayani para pasiennya. Namun, bila dibandingkan Surabaya dan Malang yang telah menerapkan prinsipprinsip untuk memaksimalkan pelayanan terhadapa lansia, saya rasa untuk Kota Jombang 
masih jauh hal itu dikarenakan hanya sekedar prosedur kesehatan biasa belum sampai memaksimalkan para pasien agar terkesan dan merasa puas.

\section{Reference}

Pratono, A.H. \& Maharani, A. (2018). Long-term care in Indonesia: The role of integrated service post for elderly. Journal of Aging and Health, 30 (10) 1556-1573

Kawakami, A. (2014), Social Implications of Long Term Care Insurance in Japan: A Review, Technology, Communication, Disparities and Government Options in Health and Health Care Services (Research in the Sociology of Health Care, Vol. 32), Emerald Group Publishing Limited, pp. 181-198 